\title{
The Implementation of the Result of Error Analysis on Writing Kata Kana to Kata Kana Learning Instructional
}

\author{
Hendri Zalman ${ }^{1, *}$ \\ ${ }^{1}$ Japanese Department, Universitas Negeri Padang, Padang, Indonesia \\ *Corresponding author. Email: hendrizalman.unp@gmail.com
}

\begin{abstract}
This article is motivated by phenomenon about the researches of the error analysis on using Japanese letters of kata kana in Indonesia. Those researches result were not implemented into kata kana learning instructional. This article purposes to developing an implementation of it's into the kata kana learning instructional. This article uses qualitative-analysis method. The finding in this article discusses about a prototype of instructional-blocks of kata kana course.
\end{abstract}

Keywords: Error analysis, using of kata kana, kata kana instructional.

\section{INTRODUCTION}

In the development of a curriculum and a course context, Print (1993) said that a teacher takes 4 of roles, namely: an implementer, an adapter, a developer, a researcher. The first, as an implementer, a teacher is needed to implement the learning process as planed it in document of curriculum. The second, as a developer, a teacher is needed to adapt the technical instructional with social and situational context of the students. The third, as a developer, a teacher is needed to developing teaching content or material as student's competences was decided. The last, as a researcher, a teacher is needed to do a research about what and how he taught, and implementing the recommendation of that research to evaluate the course in the future.

Around four of a teacher's roles above, the last role (as a researcher) is the most important role of a teacher to be a good teacher. As a researcher, a teacher would be able to identify, to make a map, to analyze, and to find an effective solution to solve the problems that happened as long as process of the course on scientific and natural way without disturbing learning process. It is meanly, by doing role as a researcher, a teacher would be able to control and increase the instructional quality effectively and continuously.
In linguistic discipline, there are many kinds of research that can be doing by a language teacher as long as doing his duty. For example: doing an action research to evaluate the learning process, and doing the descriptive-quantitative research through formative and summative test to evaluate student's progress. Beside of that, a language teacher can also conduct other research about language teaching and learning, that is an error analysis of student language using.

Brown (2007) said that a good research of error analysis in language using is not only using the descriptive approach. An error analysis in language using should be using linguistic theories as point of view, especially, using linguistic-form theories as point of view. About of the linguistic-form, Ramirez (in Tarigan, 2011) said that error in language using can be classified into morphological and syntax categories. There is no phonological category in this theory. It is mean, Ramirez saw the error analysis in language using by using the student's knowledge about the language content (factor of competence) as the point of view. Okumura and friends (2016) who did an analysis to CEFR curriculum development also have the same belief with Ramirez, they belief that linguistic-forms (especially: morphology, syntax) are related to student's competence factor. Based on belief of Ramirez and 
Naoko can be assumed that the error in morphologicalform have three criteria: using the right form of word, using the right rule of syntax in placing and structuring the word, but breaking the rule of formulating the word. Meanwhile, the criteria of error in syntax-form are: the form of word that used is fault, or the structural placement of the word is fault. The both (syntax and morphological) of this errors can be happened due to competence factor, over-generalization factor, and interference of mother-tongue. This kind of errors are named mistake, and if this happened again and again for a long time, this mistake named error.

Meanwhile, Brown (2007) used the phonological category as one of three of linguistic-form categories (phonology, morphology, syntax). Phonological categories are important because they relate to the causes of errors. Errors are not only due to competence factors, but also due to performance factors. As same as Brown, Zalman (2018) said that the error in language using can be happened due to factor of forget (kioku machigai), due to factor of slip of tongue/slip of pen (ii machigai/kaki machigai). Therefore, error analysis in language using cannot be separated with the phonological category. This kind of phonological-form of errors have some criteria: slip of tongue or slip of pen, error in writing letters that caused of error in hearing process, interference of mother tongue, and performance factor (not enough time).

In language learning context, this linguistic-form theory is directly related to the language learning theory called Form-Focus Instructional (FFI). Collins (2012) said that FFI is a language learning formula which was developed based on structural approach. Long before Collins, Dekeyser (2003) had recommended the use of FFI because it was effectively developed for learning languages that have varied linguistic-forms. It is mean, the result of research about error analysis in language using that doing analysis based on linguistic-form theory are potentially to developed to increase language learning instructional quality, for example: developing Kata Kana instructional based on the research of error analysis in using kata kana.

\section{METHOD}

The method of this research is qualitative-method. The data are taken from 5 articles of error analysis on using and writing kata kana in Indonesia. Those data are analyzed using linguistic-form analysis-approach. The result of analysis are implemented to kata kana learning instructional based on language instructional theory.

\section{FINDING AND DISCUSSION AND EQUATIONS}

\section{1. Kata Kana Instructional}

One of the unique characteristics of Japanese language is the letters that used. Japanese language uses four kinds of letters at once in written language. That letters are: Hiragana, Kata Kana, Kanji, and Romaji. Hiragana are the letters that used to write the vocabularies which are from Japan. Kata kana are the letters that used to write the vocabularies which are taken from the foreign language (Japanges language are taken a lot of vocabularies from foreign language, especially, from English language). Kanji are the letters that used to write the vocabularies which were taken from China (Mandarin Language). There are a lot of Japanese language's letters and vocabularies were taken and modified from China. The last, Romaji are the Roman's letters, as same as "huruf latin" in Indonesia language. Romaji are used to write acronym with consonant letters.

Letter in Japanese language is called moji. In a course or a learning context, Japanese letters is called hyoki, moji, and kanji (especially for kanji letters course/learning). In curriculum of Japanese Language Education Program of Universitas Negeri Padang (UNP), the course of letters is integrated into the course of vocabularies, and named as the course of mojigoi. As the course, moji goi are five gradation, that is: mojigoi 1 , mojigoi 2 , mojigoi 3 , mojigoi 4 , and mojigoi 5 . The content of the course of mojigoi 2 until moji goi 5 are letters of kanji. Kata kana and hiragana is learned on the course of mojigoi 1.

The textbook that using in the course of mojigoi 1 (content $=$ kata kana) is Kana Nyumon that published by the Japan Foundation. This textbook is used by almost all of Japanese language learning institution in Indonesia. In this textbook, conten/material about kata kana is organized and sequenced with gradation: the writing of each letter is written in order and number of the strokes, the use of kata kana into various form of words, and reading exercise. In this textbook, all of kata kana letters is written according to this gradation, the writing of kata kana that same as order and number of the strokes are the focus of instructional. So, the organize of kata kana content in this textbook can be showed like the table of instructional block below. 
Table 1. Katakana Instructional Block In Text Book of Kata Kana

\begin{tabular}{|c|c|c|c|}
\hline \multicolumn{4}{|c|}{ Unit 1} \\
\hline Contents & $\begin{array}{l}\text { Writing } \\
\text { order and } \\
\text { number }\end{array}$ & $\begin{array}{l}\text { The use of kata } \\
\text { kana into words }\end{array}$ & $\begin{array}{l}\text { Reading } \\
\text { exercise }\end{array}$ \\
\hline $\begin{array}{l}\text { ア }(\mathrm{a}) 、 イ ~ \\
(\mathrm{i}) 、 ウ(\mathrm{u}) 、 I \\
(\mathrm{e}) 、 オ \\
(\mathrm{o}) 、 カ \\
(\mathrm{ka}) 、 キ \\
(\mathrm{ki}) 、 ク \\
(\mathrm{ku}) 、 ケ \\
(\mathrm{ke}) 、 コ(\mathrm{ko})\end{array}$ & $\begin{array}{l}\text { ア }= \\
\text { イ= } \\
\text { ウ= } \\
\text { エ= } \\
\text { オ= } \\
\text { カ= } \\
\text { キ= } \\
\text { ク= } \\
\text { ケ= } \\
コ=\end{array}$ & $\begin{array}{l}A k u= \\
K a k i= \\
E k o= \\
l k e= \\
K a u= \\
\text { dan lain-lain. }\end{array}$ & $\begin{array}{l}\text { アク = } \\
\text { カキ= } \\
\text { エコ= } \\
\text { イケ= } \\
\text { カウ }= \\
\text { dan lain- } \\
\text { lain. }\end{array}$ \\
\hline \begin{tabular}{|l} 
Author- \\
Name
\end{tabular} & Alt+N & Head 3 & $\mathrm{Ctl}+3$ \\
\hline n $\quad$ Affiliatio & Alt+L & Head 4 & $\mathrm{Ctl}+4$ \\
\hline $\begin{array}{l}\text { Corresp } \\
\text { onding }\end{array}$ & $\mathrm{Alt}+\mathrm{C}$ & ListBullet & $\mathrm{Alt}+\mathrm{U}$ \\
\hline Abstract & Alt+B & ListNumbered & ${ }_{+} \mathrm{N}$ Alt+Ctl \\
\hline \begin{tabular}{|l|}
\multicolumn{1}{|c|}{ Key } \\
words
\end{tabular} & Alt+K & Table foot & ${ }_{+} \mathrm{F}^{\mathrm{Alt}+\mathrm{C} t \mathrm{l}}$ \\
\hline Equation & Alt+E & Fig caption & Alt+G \\
\hline \begin{tabular}{l|} 
Para \\
\end{tabular} & Alt+P & nt Acknowledgme & $A l t+W$ \\
\hline Head 1 & $\mathrm{Ctl}+1$ & Reference title & Alt+T \\
\hline $\begin{array}{l}\text { Referen } \\
\text { ce item }\end{array}$ & Alt+R & & \\
\hline
\end{tabular}

From the table above, we know that the book is organizing content and learning instructional based on each letters of kata kana (see: column 1). The firs activities are writing each letters of kata kana same as order and number of the strokes (see: column 2). After that, that kata kana is use to write various words, or read various word which in there are kata kana letters (see: column 3 and 4). It is mean, the content (kata kana letters) are conditioned without considering various kind of phonological aspect that have direct effect to writing of kata kana process, that are: long vocal sound, consonant sound, and other phonological characteristics. And tables should be placed either at the top or bottom of the page and close to the text referring to them if possible.

\subsection{Discussing the Result of Various Research of Error Analysis in Writing Kata Kana}

Basically, the scope of error analysis are developed based on linguistic-form theories (Brown, 2007). Therefore, various errors that found are classified according to linguistic-form, which are: phonological, morphological, and syntax categories. (Ishiwata and Takeda, 1995; Ramirez in Tarigan, 2011). The use of this linguistic-form categories are related to two big theories, which are: the linguistic theory, and the language learning theory. The linguistic theory that influences the error analysis is the structural of language theory. Meanwhile, the language learning theory that influences the error analysis is the Form-Focus Instructional (FFI) theory. In linguistic-form context, error analysis in writing kata kana is directly related to phonological form.

There are many researches about error analysis in Japanese language using that discuss about the error in writing kata kana. All of that researches are summarized below of some of research theme, which are: error analysis in writing gairaigo, error analysis in using kata kana, error analysis in writing kata kana, and other themes. From all of that researches, the researchers who use linguistic-form or phonological analysis are not many. Almost, all of the researchers that did an error analysis only describing what kind of objects (letters) are fault, and how many times that fault happened. Therefore, this article try to summarize of the finding and discussion that five researchers wrote on their error analysis in writing kata kana.

First, the research of Sepni et al (2015) about error analysis of SMA at Sumatera Barat students on writing kata kana. This research describe that there are two types of student's error, which are: writing error cause of broke the order and number of the strokes, error on using kata kana to write gairaigo (especially, the word that taken from English language). Writing errors in order and number of the strokes are caused by factor of student' memory (do not remember the rule). Errors on using kata kana to write gairaigo are caused by factor of student ability on English language. From this finding, we can assume that the researchers only used a descriptive-approach, and did not doing an analysis in linguistic-form context.

Second, Kamal et al (2017) who did research about student's error on using kata kana. The finding of this research discussing about the cause of student's error, which are: factor of competence, breaking the rule, and over generalization. Factor of competence is described 
as the student's un-ability on reading and writing kata kana. Factor of breaking the rule is described as the student's unknowing about the rule on using kata kana. Meanwhile, factor of over generalization is described as the student's un-ability on identifying the different between the letters which have similar form. As same as the first one, this research only used the descriptiveapproach, and did not doing an analysis based on linguistic-form context.

Third, Susriyani et al (2018) who did the research about student's error on reading kata kana in form of words. The finding of this research describing the student's errors on: reading kata kana (with dakuten mark) on form of words, reading kata kana (with double consonant at end of letter). The cause of both of errors are factor of learning strategy and situational context of sociolinguistic. As same as the first and the second researches, this research also using descriptiveapproach, and did not doing an analysis on linguisticform context.

Fourth, Pratama et al (2016) who did a research about student's error on using kata kana when writing gairaigo. The finding of this research showed that the main factor which is caused students error is the student's un-ability on identified long-sound (chouon). In fact, the length of the student's study period has no effect on the writing error of chouon with this kata kana. This finding showed that this fourth research used the different analyzing-technic than the three research before. In this fourth research, Pratama et al already did the linguistic-form approach (phonological-approach) on analyzing process.

Fifth, Sari (2017) who did a research about students of Universitas Negeri Padang error on using kata kana. The finding of this research showed that the student's error on using kata kana are happened on: writing the long-sound, writing word with "-ar" and "-er" consonant-sound at the end of word. As the same as the fourth research, this fifth research also analyzed their data using linguistic-form approach, that is phonological approach. The findings of the analysis from the point of view of sound (phonology) show that the long sounds and consonant-sound at the end must get attention in the process of learning kana.

The five researches above can be classified into two categories, which are: the researches with number one until three (1-3), and the researches with number four and five $(4,5)$. On the researches with number one until number three are found three similarity things. The first, the three of researches about error analysis on kata kana above are using the same of analysis approach, which is descriptive-approach. The second, on linguistics aspect, the three researches did not using linguistic-form theory (phonology) as the basis of analysis theory. The third, on language-learning aspect, the three researches also did not analyzed that their study have or have not relation with language-learning theory, which is called FFI theory.

On linguistic aspect, the three of researchers of error analysis on kata kana have the same tendency, which is doing analysis based on sociolinguistic aspect as point of view, especially, psychology of the students. This thigs can be showed from the tendency of the point of the finding or discussion, which is what the factors which cause student's error are. The factors which caused error that found are: factor of competence, factor of over-generalization, and factor of disobeying of the rule of using kata kana. These tendencies have an impact on the follow-up to the way of student error controlling, which all of them recommend that students/students practice diligently, and teachers/lecturers diligently provide kata kana practice.

On language-learning aspect, the tendency which found is the researchers are not familiar with FFI. This thing can be showed from the tendency of the researchers who directly making recommendation practice the kata kana as the solving of the problem. There are no any discussion about to evaluate the previous or ongoing instructional of kata kana (for example: evaluation of material/content organizing, method, and so on). There are also no discussion about the implementation or contribution of the findings of the researches systematically (at least contains content and learning gradations).

Meanwhile, on the fourth and the fifth research also found the same tendency, which is doing analyze to the aspect sound (phonological aspect). The fourth research focused on the long-sounds as the difficult soundcharacter to be written by the students. The fifth research focused on the long-sound and the consonantsound at the end as the difficult sound-character to be written by the students. The main point of this two researches is that the instructional of kata kana teachers should take a serious attention to the system of the sound (phonological system) when developing kata kana instructional. For example: a teacher should developing the instructional content of kata kana according to the long-short of the sound, the sound at the end of word (Japanese phonological system). Then, structuring learning-activities sequent according that content difficulty-degree.

On language-learning context, Sakoda (2009) did a long research about student's error on using Japanese languages and those error relations with learning content/material organizing and sequencing on the textbook, and student's language competence. Sakoda found that the student's error on Japanese language (on using the particle of "de and "ni") are not related to student's language competence. This thing can be showed from the one who did the error, which are the students from different competence level did the same error. It is meant that there is another factor, which is: 
factor of over-generalization which is caused by the content/material organizing on the textbook, and teacher following it as learning method. That content/material organizing and sequencing influence the students to do over-generalization things when building the concept. The same case is also found by Zalman (2016) on his research "Language Production Strategy which Potentially Causing Error in Japanese". On this research, Zalman said that students error on producing sentences in Japanese language is also caused of content organizing and sequencing in the textbook. The students with full awareness did a learning strategy, which is doing generalization according what their thinks after reading the text book.

3.3. The Implementation of the Result of Error Analysis on Writing Katakana to Kata Kana Learning Instructional

To follow-up the research's result of error analysis on writing kata kana above, this article will make an instructional-block of Kata Kana's content/material organizing base on two of main theories: phonological system of Japanese Language of Gairaigo theory (Zalman, 2014), and organizing instructional block theory (Richard, 2001). Phonological system of Japanese Language of Gairaigo theory is developed as contents/material, and organized like the table of instructional block below.

Table 2. Units of Katakana Instructional Block Based on Phonological System of Gairaigo

\begin{tabular}{|c|c|c|c|}
\hline \multicolumn{4}{|c|}{ Units 1} \\
\hline Contents & $\begin{array}{c}\text { Phonological } \\
\text { system }\end{array}$ & Gairaigo & $\begin{array}{l}\text { Writing on } \\
\text { Katakana }\end{array}$ \\
\hline $\begin{array}{l}\text { Consonant- } \\
\text { sound at the } \\
\text { end }\end{array}$ & $\begin{array}{l}\sim \mathrm{t}-\sim \mathrm{to}, \\
\sim \mathrm{d}-\sim \mathrm{do} \\
\sim \mathrm{te}, \sim \mathrm{de} \\
\sim \mathrm{b}, \sim \mathrm{g}, \quad \sim \mathrm{k}, \\
\sim \mathrm{m}, \quad \sim \mathrm{p}, \sim \mathrm{s}, \\
\sim \mathrm{bu}, \quad \sim \mathrm{gu}, \\
\sim \mathrm{ku}, \quad \sim \mathrm{mu}, \\
\sim \mathrm{pu}, \sim \mathrm{su}\end{array}$ & $\begin{array}{l}\text { Hint, stand } \\
\text { Note, } \\
\text { shade } \\
\text { Club, dig, } \\
\text { snack, } \\
\text { cream, } \\
\text { group, kiss }\end{array}$ & $\begin{array}{l}\text { Hinto, } \\
\text { sutando } \\
\text { No-to, se-do } \\
\text { Kurabu, } \\
\text { diggu, kuri- } \\
\text { mu, guru-pu, } \\
\text { kissu }\end{array}$ \\
\hline \multicolumn{4}{|c|}{ ru, our } \\
\hline Contents & $\begin{array}{c}\text { Phonological } \\
\text { system }\end{array}$ & Gairaigo & $\begin{array}{l}\text { Writing on } \\
\text { Katakana }\end{array}$ \\
\hline Long sound & $\begin{array}{l}\text {-ar-, -er, -ir, } \\
\text { ur-, -or- "-“" }\end{array}$ & $\begin{array}{l}\text { Garden } \\
\text { Lever } \\
\text { Sir } \\
\text { Turn } \\
\text { Form } \\
\end{array}$ & $\begin{array}{l}\text { ga-den } \\
\text { reba- } \\
\text { sa- } \\
\text { ta-n } \\
\text { fo-mu }\end{array}$ \\
\hline \multicolumn{4}{|l|}{ Units 3} \\
\hline Contents & $\begin{array}{c}\text { Phonological } \\
\text { system }\end{array}$ & Gairaigo & $\begin{array}{l}\text { Writing on } \\
\text { Katakana }\end{array}$ \\
\hline $\begin{array}{l}\text { Double- } \\
\text { consonant }\end{array}$ & & $\begin{array}{l}\text { Appeal } \\
\text { Butter } \\
\text { Approach } \\
\text { Assistant }\end{array}$ & $\begin{array}{l}\text { Api-ru } \\
\text { Bata- } \\
\text { Apuro-chi } \\
\text { Asisutanto }\end{array}$ \\
\hline
\end{tabular}

\begin{tabular}{|c|c|c|c|}
\hline & & Attraction & Atorakushon \\
\hline
\end{tabular}

On the table of instructional block above, units of instructional are not organized based on order and number of the strokes of kata kana. Contents are organized and sequenced base on the soundcharacteristic of the words, especially the soundscharacter that do not have a special letters. Those kind of sounds potentially making the students doing error on writing the word in kata kana letters. Richard (2001) said that the difficult contents should be priority things when developing language learning instructional block.

On the unit-one, the unique-characteristic which developed become the content is the writing the words with consonant-letters at the end of words (column 1), those are: " $\mathrm{t}$ " and " $\sim \mathrm{d}$ " consonants, and other consonants. The writing of consonants at the end of words is a serious problem to Japanese languageIndonesian learners, those are caused by the fact that kata kana have not the consonant letter. Therefore, the priority on this unit is to give students many words of Gairaigo with consonant letter at the end of the words (column 2), and the students are designed to write all of words (column 3). On the last column (column 4), there are the keys (the right writing of the words based on the rules of writing the Gairaigo) as the reflection, the students combine what they wrote with what are on column 4 , and doing self-reflection.

Learning activities on the unit 2, 3, and next are same as the unit 1 . The unique-characteristic which developed as the content are: the words which sounded with the long sound (unit 2; column 1,2 ), and the words which have double-consonant (unit 3; column 1, 2). On these units (unit 2, 3), there are also reading words activities to diagnostic student's error on writing before they write the words (error on writing which caused of error on sounding the words). The last, the content on column 4 is the guide for the students to do selfreflection.

\section{CONCLUSION}

Language as a science (linguistic) and language as a learning-media is related, not separated. Based on the discussion above, we know that the linguistic-analysis should be used to evaluate and to develop the quality of language learning instructional. The point of the discussion above is that the result of the researches of error analysis on kata kana which used linguisticanalysis (phonological analysis) are able to make kata kana learning instructional more effective and efficient. 


\section{REFERENCES}

[1] Collins, L. (2012). Instruksi bentuk fokus. Ensiklopedia Linguistik Terapan. New York: Penerbitan Blackwell.

[2] Dekeyser, RM (2003). Pembelajaran Tersirat dan Eksplisit. dalam C. Doughty \& MH Long (Eds.), Buku Pegangan Akuisisi Bahasa Kedua (hlm. 313340). Malden, MA: Pub Blackwell.

[3] Ishiwata dan Takeda. 1995. Taishogengogaku (Edisi 6). Tokyo: Oufuu.

[4] Kamal, Ahmad Azhar \& Firmansyah, Dian Bayu \& Setiana, Soni Mulyawan. "Faktor Penyebab Kesalahan Penggunaan Huruf Katakana". Jurnal "Janaru", Volume VI, Nomor 1, Mei 2017.

[5] Okumura, Minako \& Sakurai, Naoko \& Suzuki, Yuko. 2016. Nihonggo Kyoshi no Tame no CEFR. Japan: Kabushiki Kaisha.

[6] Pratama, Septian Eka \& Herniwati \& Renariah. 2016. "Analisis Kesalahan Penulisan Gairaigo pada Mahasiswa Tk. I s.d. IV Pemokusan pada Gairaigo Bahasa Inggris". Jurnal Pendidikan dan Pengajaran Bahasa Jepang "JAPANEDU", Volume 1, Nomor 2, Tahun 2016.

[7] Print, Murray. 1993. Curriculum Development and Designs. USA: Allen \& Unwin.

[8] Richard, Jack C. 2001. The Origins of Language Curriculum Development. USA: Cambridge University.

[9] Sepni, Rahtu Nila \& Sastra, Gusdi \& Yusri, Lady Diana. 2015. "Analisis Kesalahan Penulisan Kana Siswa SLTA Sumatera Barat". Jurnal "Kotoba", Jilid 2, 2015.

[10] Susriyani, Desi \& Hadriana \& Rahayu Nana. 2018. "Factors and Analysis Of Misread Of Katakana Vocabularies by Second Grade Student (2016/2017) Japanase Education Program FKIP UNRI". JOM FKIP, Volume 5, Edisi 1 JanuariJuni 2018.

[11] Sari, Widya Agus Syamsi. 2017. "Analysis of Error in Writing Katakana Letter on the Hyouki Test by Students of Japanese Language Educational Study Program". Skripsi thesis, Universitas Negeri Padang. http://repository.unp.ac.id/19680/.

[12] Tarigan, Henry Guntur \& Tarigan Djago. 2011. Pengajaran Analisis Kesalahan Berbahasa: Edisi Revisi. Bandung: Angkasa.

[13] The Japan Foundation. 1990. Kana Nyumon. Jakarta: The Japan Foundation.
[14] Zalman, Hendri. 2014. Kosakata Bahasa Jepang Dasar. Padang: FBS UNP Press.

[15] Zalman, Hendri. 2016. "Language Production Strategy which Potentially Causing Error in Japanese". Komposisi: Jurnal Pendidikan Bahasa dan Seni. Padang: UNP.

[16] Zalman, Hendri. 2018. "Belajar dari Kesalahan: Analisis Kemampuan dan Analisis Kesalahan sebagai Evaluasi Dua Dimensi". (di dalam) Prosiding "Seminar Nasional Pembelajaran Bahasa Jepang ASPBJI Korwil Sumbar, tahun 2018. http://repo.unand.ac.id/20302/. [2] [1] 